UDK 632.51: 631.531

Naučni rad-Scientific paper

\title{
Biološka produkcija korovske vrste Abutilon theophrasti Medik. različitog geografskog porekla
}

\author{
${ }^{1 *}$ Dragana Božić, ${ }^{1}$ Nevena Nikolić, ${ }^{1}$ Nikola Obradović, ${ }^{2}$ Donato Loddo, ${ }^{3}$ Darko Stojićević, \\ ${ }^{1}$ Markola Saulić, ${ }^{1}$ Aleksandra Savić, ${ }^{1}$ Sava Vrbničanin \\ ${ }^{1}$ Univerzitet u Beogradu, Poljoprivrdni fakultet, Beograd, Srbija; ${ }^{2}$ Institute of Agro-environmental and \\ Forest Biology - CNR, Legnaro, PD, Italy; ${ }^{3}$ Visoka tehnička škola strukovnih studija, Požarevac \\ *e-mail: dbozic@agrif.bg.ac.rs
}

\section{REZIME}

Biološka produkcija 12 populacija korovske vrste Abutilon theophrasti Medik. različitog geografskog porekla, je proučavana u našim agroekološkim uslovima. Semena ovih populacija su sakupljena u fazi fizičke zrelosti na sledećim lokalitetima: Katalonija-Španija (CAT), Hrvatska (CRO), Grčka (GRE), Mađarska (HUN), Ajova-SAD (IOWA ), Legnaro-Italija (ITA), Minesota-SAD (MIN), Portugal (POR), Srbija (SER), Slovenija (SLO), Arganda-Španija (SPA) i Piza-Italija (TOS). U jesen 2013. godine semena su posejana na oglednom dobru Poljoprivrednog fakulteta "Radmilovac" u gustini od 1 biljke na $0,25 \mathrm{~m}^{2}$. U fazi plodonošenja mereni su brojni vegetativni (visina stable, dužina korena, broj grana, broj listova, površina listova) i generativni (broj čaura, prečnik čaura, broj kućica u čauri, masa semena po biljci) parametri.

Analizom merenih parametara potvrđeno je da se biološka produkcija ispitivanih populacija razlikuje, u zavisnosti od ispitivanog parametra. Kod vegetativnih parametara najizraženije razlike su konstatovane kod površine listova, dok su kod generativnih parametra najizraženije razlike utvrđene za broj čaura i masu semena po biljci.

Ključne reči: Abutilon theophrasti Medik., biološka produkcija, geografsko poreklo, vegetativna produkcija, generativna produkcija. 


\section{UVOD}

Korovska vrsta Abutilon theophrasti Medik. (familija Malvaceae) u narodu je poznata kao Teofrastova lipca, lipica, žutoslez, želudarka. Kao jednogodišnja zeljasta vrsta (terofit, T4) razmnožava se semenom, čija produkcija po biljci iznosi 1800 -20 000 semena. Što se tiče ekoloških osobina ove vrste, to je kasnoprolećna vrsta koja klija i niče od aprila do maja meseca (optimalna temperature je $16^{\circ} \mathrm{C}$ ), na dubini manjoj od $10 \mathrm{~cm}$ (Vrbničanin i Šinžar, 2003). Njen odnos prema hranivima, svetlosti, vlazi i temeparaturi ukazuje da ima široku ekološku nišu u poređenju sa mnogim drugim korovskim vrstama (Warwick i Black, 1988).

A. theophrasti se svrstava u najproblematičnije korove u SAD (Stoller i sar., 1993), Kanadi (Warwick i Black, 1986) i Evropi (Sattin i sar., 1992), gde može da dovede do gubitaka u prinosu najzastupljenijih useva (npr. kukuruza) i do 80\%, u zavisnosti od agroekoloških uslova i gustine korova (Lindquist i sar., 1998). Gubitak prinosa useva prouzrokuje preko kompeticije, alelopatskog uticaja, ali i kao biljka domaćin štetočina i patogena useva. U našoj zemlji je konstatovana pre II svetskog rata i od tada se širi iz pravca severa, a trenutno je u ekspanziji prema jugu. Kartiranjem je utvrđeno prisustvo ove vrste na području Vojvodine, Mačve, Šumadije i u dolinama većih reka Srbije (Vrbničanin i sar., 2008). Najveći problem predstavlja u jarim okopavinama kao što su šećerna repa, soja, kukuruz, suncokret, ali i u povrtnjacima, zasnovanim lucerištima i deteliništima i intenzivnim višegodišnjim zasadima (voćnjacima i vinogradima).

A. theophrasti predstavlja posebno kompetitivnu i postojanu korovsku vrstu u njivama, kao i na ruderalnim staništima (površine pored puteva, pruga, građevinsko zemljište, okućnice, uvratine, međe, rubovi njiva, itd.). Zahvaljujući produkciji velikog broja semena, koja imaju visoku vitalnost, izraženu osobinu mirovanja semena, kao i sposobnost produkcije semena tokom kompeticije, ova vrsta se ubraja u veoma problematične korove (Warwick i Black, 1988). Efikasne mere suzbijanja podrazumevaju primenu agrotehničkih mera i herbicida, ali i upoznavanje sa odlikama vrste, uključujući i njenu biološku produkciju.

Biološka produkcija korova zavisi od različitih faktora uključujući biološke, klimatske i edafske, koji utiču na njihovu pojavu, brojnost, raznovrsnost i distribuciju. Bilo koja promena nekog od navedenih faktora može biti ograničavajući faktor razvoja biljaka (Robbins, 1965) ukoliko smanjuje njihovu sposobnost da rastu svojim najvećim potencijalom. Proučavanje biološke produkcije, a pre svega prinosa je prvenstveno usmereno na useve, a ređe na korovske vrste. Ipak, poznavanje produkcije korovskih biljaka je značajno, jer se sprečavanjem produkcije semena tokom dužeg perioda mogu značajno redukovati rezerve semena u zemljištu (Hartzler, 1996). Stoga je razvoj mera usmerenih na redukciju produkcije semena korovskih biljaka poželjan, ali prvi korak u tom procesu treba da bude utvrđivanje produktivnosti korovskih vrsta. 
Cilj ovog rada bio je da se utvrdi biološka produkcija populacija $A$. theophrasti različitog geografskog porekla (12 populacija iz 12 regiona) u slučaju kada su ove populacije gajene $\mathrm{u}$ istovetnim agroekološkim uslovima kakvi su na području Beograda.

\section{MATERIJAL I METODE}

Semena 12 populacija vrste $A$. theophrasti su sakupljena u jesen 2013. godine u fazi fizičke zrelosti na lokalitetima: Katalonija-Španija (CAT), Hrvatska (CRO), Grčka (GRE), Mađarska (HUN), Ajova-SAD (IOWA ), Legnaro-Italija (ITA), Minesota-SAD (MIN), Portugal (POR), Srbija (SER), Slovenija (SLO), Arganda-Španija (SPA) i Piza- Italija (TOS). Iste jeseni je obavljena setva na oglednom dobru Poljoprivrednog fakulteta "Radmilovac". Ogled je postavljen na zemljištu tipa praškasta ilovača (Tab.1). Setva je obavljena ručno 22.11.2013. na dubinu od $2 \mathrm{~cm}$, a nakon nicanja biljaka u proleće naradne godine urađeno je ručno proređivanje tako da je na svakih $0,25 \mathrm{~m}^{2}$ ostavljena po 1 biljka. Sve korovske vrste na eksperimentalnom polju izuzev zasejanog A.theophrasti uklanjane su ručno-plevljenjem tokom čitave vegetacije. Veličina elementarne parcele je iznosila $1 \mathrm{~m}^{2}$, a svaka populacija zasejana je na 4 elementarne parcele. Meteorološki podaci za period trajanja ogleda dati su u Tab.2.

Tabela 1. Mehanički i hemijski sastav zemljišta

Table 1. Soil composition and chemical analysis

Mehanički sastav zemljišta (\%)

\begin{tabular}{ccccccc}
\hline Pesak (ukupno) & Pesak & Pesak & Prah & Prah & $\begin{array}{c}\text { Koloidi gline } \\
\text { Higroskopna } \\
\text { vlaga }\end{array}$ \\
\hline $2-0,05 \mathrm{~mm}$ & $0,2-0,05 \mathrm{~mm}$ & $2-0,2 \mathrm{~mm}$ & $0,05-0,01 \mathrm{~mm}$ & $0,01-0,002 \mathrm{~mm}$ & $<0,002 \mathrm{~mm}$ & \\
\hline 8,0 & 4,81 & 3,21 & 33,8 & 33,04 & 25,14 & 3,36 \\
\hline
\end{tabular}

Hemijski sastav zemljišta

\begin{tabular}{|c|c|c|c|c|c|c|}
\hline$\% \mathrm{CaCO}_{3}$ & $\mathrm{pH} \mathrm{u} \mathrm{H}_{2} \mathrm{O}$ & $\mathrm{pH} \mathrm{u} \mathrm{KCl}$ & $\%$ humusa & $\% \mathrm{~N}$ & $\begin{array}{c}\mathrm{mg} \mathrm{K}_{2} \mathrm{O} / \\
100 \mathrm{~g} \text { zemljišta }\end{array}$ & $\begin{array}{c}\mathrm{mg} \mathrm{P}_{2} \mathrm{O}_{5} / \\
100 \mathrm{~g} \text { zemljišta }\end{array}$ \\
\hline 8,0 & 4,81 & 3,21 & 33,8 & 33,04 & 25,14 & 3,36 \\
\hline
\end{tabular}


Tabela 2. Meteorološki podaci na lokalitetu Radmilovac tokom trajanja ogleda

Table 2. Meteorological data for locality Radmilovac during experiment

\begin{tabular}{lcc}
\hline Mesec & Suma padavina $(\mathrm{mm})$ & Prosečna temperatura $\left({ }^{\circ} \mathrm{C}\right)$ \\
\hline Novembar & 54,2 & 9,7 \\
Decembar & 2,6 & 2,6 \\
Januar & 5,3 & 34 \\
Februar & 7,7 & 7,5 \\
Mart & 10,9 & 47,5 \\
April & 13,7 & 77,3 \\
Maj & 16,9 & 286 \\
Jun & 22,2 & 50,5 \\
Jul & 23,5 & 255,7 \\
Avgust & 22,7 & 109,5 \\
\hline
\end{tabular}

U fazi plodonošenja (polovina avgusta 2014. godine) biljke su uzorkovane radi merenja vegetativnih [dužina stabla $(\mathrm{cm})$, dužina korena $(\mathrm{cm})$, broj grana, broj listova, površina listova $\left(\mathrm{cm}^{2}\right)$ ] i generativnih parametara [broj čaura, broj semenih kućica, prečnik čaura $(\mathrm{mm})$, masa semena $(\mathrm{g})]$.

Statistička analiza dobijenih rezultata je urađena u softverskom paketu STATISTICA 5.0 pomoću t-testa.

\section{REZULTATI I DISKUSIJA}

Poznavanje uticaja različitih faktora na produkciju korovskih vrsta ima veliki značaj za predviđanje opstanka i širenja korovskih populacija, kao i za planiranje njihovog suzbijanja u sistemu integralnih mera. Vegetativna produkcija korova je značajna za procenu kompetitivnosti vrsta i zavisi od naslednih osobna vrste, gustine populacije i meteoroloških uslova. Značaj generativne produkcije ogleda se u njenom uticaju na rezerve semena u zemljištu, a time i opstanak i širenje populacija.

Vegetativna produkcija $A$. theophrasti: Vrsta $A$. theophrasti se svrstava u grupu korova koja, generalno, ima veliku vegetativnu produkciju, zbog čega ova vrsta ima veliku visinu i relativno krupne listove. Visina ove vrste, grananje i dužina internodija veoma zavise od dostupne 
svetlosti. Poznato je da je rast $A$. theophrasti u početnim fazama razvoja sporiji nego rast različitih useva (Sattin i sar., 1992; Tremmel i Bazzaz, 1994), što u slučaju kada su usevi posejani u optimalnom roku, daje kompetitivnu prednost gajenim biljkama.

Analizom rezultata, koji se odnose na vegetativnu produkciju populacija $A$. theophrasti različitog geografskog porekla, utvrđena je veoma izražena intrapopulaciona varijabilnost na nivou većine vegetativnih parametara. Međutim, kada je u pitanju interpopulaciona varijabilnost značajne razlike $(\mathrm{P}<0,05) \mathrm{u}$ vegetativnim parametrima su zabeležene samo između pojedinih populacija (SPA : GRE, SER, HUN, ITA; zatim IOWA : SER i GRE), i bile su najizraženije za parametar površina lista.

Prosečna visina biljaka (Graf. 1a) ispitivanih populacija A. theophrasti kretala se od $65,00 \pm 32,60 \mathrm{~cm}$ (GRE) do $150,58 \pm 17,42 \mathrm{~cm}$ (SPA), dok je prosečna visina biljaka svih ispitivanih populacija bila $102,12 \pm 25,10 \mathrm{~cm}$. Visina polovine ispitivanih populacija (CRO, GRE, HUN, ITA, SER, SLO) je bila ispod proseka, dok je preostalih 6 populacija imalo veću visinu od prosečne (Tab.3). Izmerene visine biljaka su bile niže u poređenju sa visinom ove vrste koja je zabeležena u prethodnim istraživanjima na našem području. Naime, u istraživanjima kompetitivnih odnosa A. theophrasti i kukuruza, Onć-Jovanović (2014) je utvrdila da se prosečna visina biljaka ove vrste, u uslovima monokulture u zavisnosti od gustine, kretala oko 160-175 cm. Nasuprot tome, $\mathrm{u}$ agroekološkim uslovima Ajove biljke iste vrste su dostigle visinu $88-96 \mathrm{~cm}$ u uslovima optimalne osvetljenosti (Bello i sar.,1995).

Stopa rasta korenovog sistema $A$. theophrasti prevazilazi mnoge korovske vrste, pri čemu u povoljnim ekološkim uslovima može dostići dubinu od 1,7 do 1,9 m (Evetts i Burnside, 1973). Prosečna dužina korena populacija $A$. theophrasti različitog geografskog porekla u ovom istraživanju je bila znatno manja i kretala se od $13,43 \pm 5,01 \mathrm{~cm}$ (SLO) do $20,30 \pm 8,59 \mathrm{~cm}$ (POR) (Graf. 1b), dok je na nivou svih ispitivanih populacija prosečna vrednost ovog parametra bila $16,45 \pm 2,11 \mathrm{~cm}$. Biljke populacija IOWA, POR i SPA su imale razvijeniji koren nego ostale populacije (Tab. 3). Ove populacije su, takođe, bile razvijenije i u odnosu na druge parametre, što se može dovesti u vezu sa razvijenošću korena, od koje zavisi usvajanje vode i hraniva iz zemljišta.

Grananje stabla vrste $A$. theophrasti zavisi pre svega od stepena zasenjenosti kada raste $\mathrm{u}$ uslovima kompeticije sa drugim bilikama. Bello i saradnici (1995) su utvrdili da biljke ove vrste u uslovima oprimalne osvetljenosti razvijaju 11 do 18 grana. Slični rezultati su dobijeni i za populacije $A$. theophrasti ispitivane u ovom radu, pri čemu je najveći broj bočnih grana imala populacija MIN $(18,20 \pm 5,89)$, dok je najmanji broj grana utvrđen za populaciju SER $(9,00 \pm 5,05)$ poreklom sa naših prostora (Graf. 1c). Prosečan broj grana na nivou svih ispitivanih populacija je bio $15,28 \pm 4,53$ (Tab. 3), pri čemu je većina populacija prevazilazila ovu prosečnu vrednost, dok je znatno slabije grananje konstatovano za populacije GRE, ITA i SER. 
Broj listova populacija poreklom iz različitih geografskih područja je varirao od 8,25 $\pm 6,55$ (CRO) do 29,33 $\pm 26,90$ (POR) (Graf. 1d), prosečna vrednost za sve populacije je bila 15,79 $\pm 7,36$. Populacije CAT, IOWA, POR, SLO, SPA su imale veću vrednost ovog parametra od opšteg proseka, dok je kod ostalih popualcija njegova vrednost bila manja (Tab.3). Dobijeni rezultati su u suprotnosti sa rezultatima do kojih su došli Bello i sar. (1995) u agroekološkim uslovima Ajove. U njihovim istraživanjima biljke $A$. theophrasti su imale preko 40 listova, što je znatno više od broja listova koji je utvrđen kod populacija ispitivanih u ovom radu.
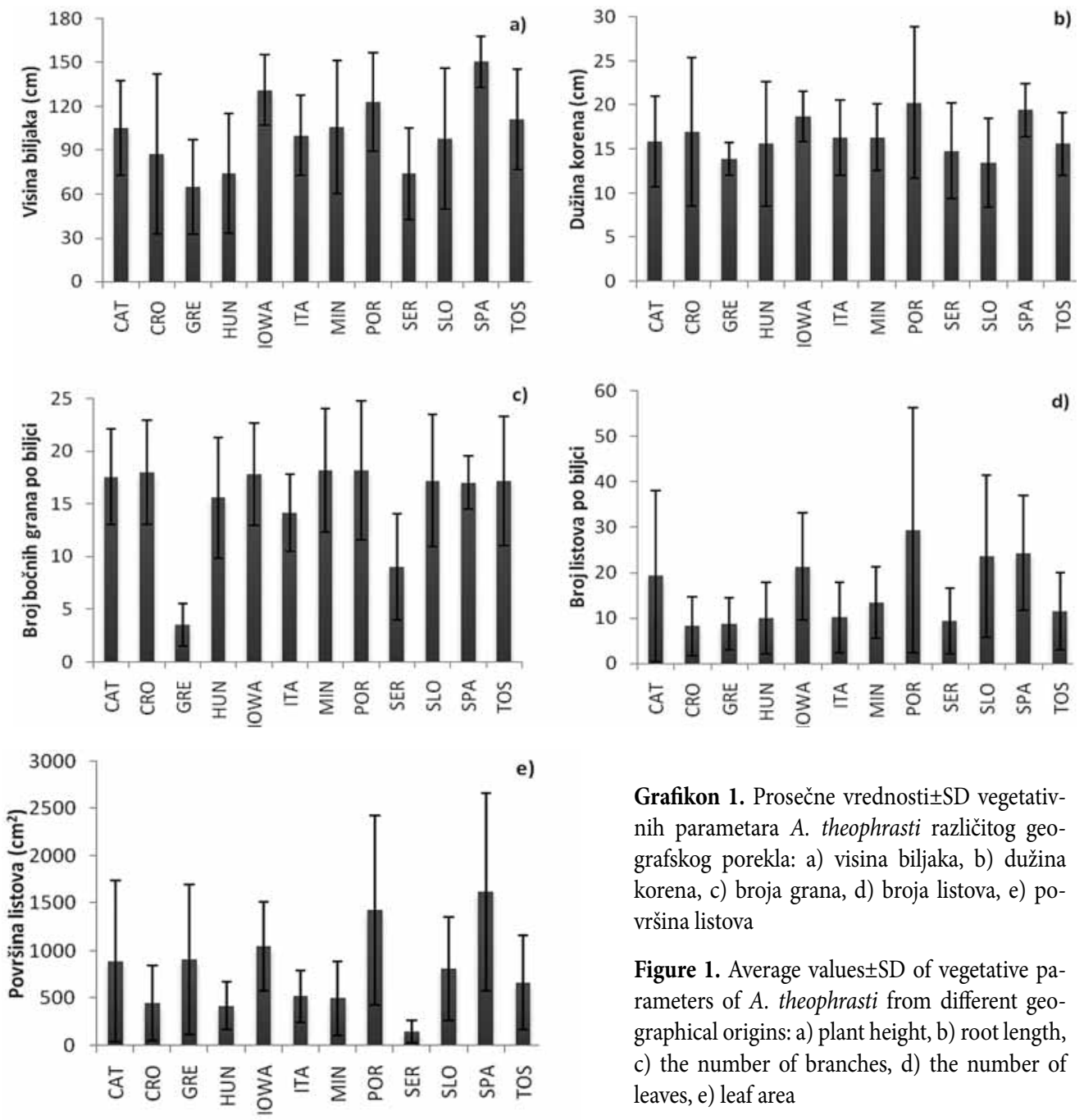

Grafikon 1. Prosečne vrednosti \pm SD vegetativnih parametara $A$. theophrasti različitog geografskog porekla: a) visina biljaka, b) dužina korena, c) broja grana, d) broja listova, e) površina listova

Figure 1. Average values $\pm S D$ of vegetative parameters of $A$. theophrasti from different geographical origins: a) plant height, b) root length, c) the number of branches, d) the number of leaves, e) leaf area 
Ukupna površina listova po biljci kod ispitivanih populacija bila je veoma varijabilna i kretala se od 146,33 $\pm 160,64 \mathrm{~cm}^{2}$ (SER) do $1623,44 \pm 1044,72 \mathrm{~cm}^{2}$ (SPA) (Graf. 1e), a prosečna vrednost ovog parametra za sve populacije je iznosila $783,97 \pm 429,51 \mathrm{~cm}^{2}$. Uglavnom su se populacije koje su imale veći broj listova, izdvojile i kao populacije sa većom površinom listova u poređenju sa opštim prosekom ovog parametra za sve ispitivane populacije. Dobijeni rezultati ukazuju da su sve populacije postigle znatno manju površinu listova u poređenju sa biljkama poreklom sa našeg podneblja, koje su gajene u našim agroekološkim uslovima tokom 2008. i 2009. godine. Površina listova ovih biljaka gajenih u monokulturi, kretala se između 1500 i $6500 \mathrm{~cm}^{2}$ (OnćJovanović, 2014).

Tabela 3. Karakteristike populacija A. theophrasti u odnosu na prosečne vrednosti vegetativnih parametara za svih 12 populacija

Table 3. Characteristics of $A$. theophrasti populations in comparison with average values of vegetative parameters for all 12 populations

\begin{tabular}{|c|c|c|c|c|c|c|c|c|c|c|c|c|c|}
\hline & Prosek \pm SD & 憂 & 원 & 空 & 㝋 & $\sum_{0}^{\frac{1}{0}}$ & 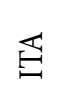 & 光 & 잉 & 㐍 & $\stackrel{0}{\leftrightarrows}$ & $\underset{\infty}{\overleftarrow{s}}$ & $\tilde{0}$ \\
\hline \multirow{2}{*}{$\begin{array}{l}\text { Visina } \\
(\mathrm{cm})\end{array}$} & $<102,12 \pm 25,10$ & & + & + & + & & + & & & + & + & & \\
\hline & $>102,12 \pm 25,10$ & + & & & & + & & + & + & & & + & + \\
\hline \multirow{2}{*}{$\begin{array}{l}\text { Dužina } \\
\text { korena }(\mathrm{cm})\end{array}$} & $<16,45 \pm 2,11$ & + & & + & + & & + & + & & + & + & & + \\
\hline & $>16,45 \pm 2,11$ & & + & & & + & & & + & & & + & \\
\hline \multirow[t]{2}{*}{ Broj grana } & $<15,28 \pm 4,53$ & & & + & & & + & & & + & & & \\
\hline & $>15,28 \pm 4,53$ & + & + & & + & + & & + & + & & + & + & + \\
\hline \multirow[t]{2}{*}{ Broj listova } & $<15,79 \pm 7,36$ & & + & + & + & & + & + & & + & & & + \\
\hline & $>15,79 \pm 7,36$ & + & & & & + & & & + & & + & + & \\
\hline \multirow{2}{*}{$\begin{array}{l}\text { Površina } \\
\text { listova }\end{array}$} & $<783,97 \pm 429,51$ & & + & & + & & + & + & & + & & & + \\
\hline & $>783,97 \pm 429,51$ & + & & + & & + & & & + & & + & + & \\
\hline
\end{tabular}

Generativna produkcija $A$. theophrasti: Generativna produkcija korovskih biljaka je značajna za opstanak i širenje vrsta, kao i za zakorovljenost useva. Poznato je da generativna produkcija A. theophrasti, zavisi od različitih faktora kao što su: vreme nicanja, kompetitivne interakcije sa usevom, dostupna svetlost, itd. (Teasdale, 1998, Benvenuti i sar., 1994, Bello i sar., 1995). 


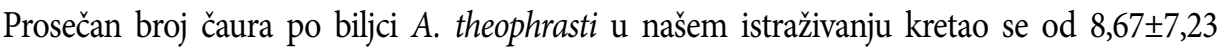
(GRE) do 65,80 $\pm 43,49$ (IOWA) (Graf. 2a), pri čemu je prosek za sve posmatrane populacije iznosio $34,10 \pm 16,08$. Populacije CAT, IOWA, MIN, POR i SLO su se izdvojile kao populacije sa većom produkcijom čaura od proseka za svih 12 populacija (Tab. 4). Ostvarena produkcija čaura po biljci je znatno veća od produkcije koju su zabeležili Onć-Jovanović i saradnici (2011), pri čemu je ova vrsta u našim agroekološkim uslovima u jednoj vegetacionoj sezoni imala produkciju 22-36 čaura po biljci. Nasuprot tome, produkcija koju su isti autori zabeležili tokom druge veregetacione sezone je bila znatno manja (16-26 čaura po biljci), što je bliskije rezultatima za populacije CRO, GRE, HUN, ITA, SER, SPA i TOS, ostvarenim u našem istraživanju.

Uprkos tome što su se ispitivane populacije veoma značajno razlikovale u pogledu pro-

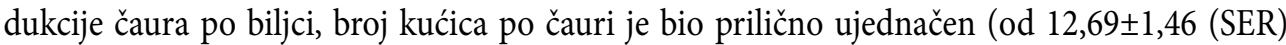
do $14,52 \pm 0,79$ (IOWA)) (Graf. 2 b), a prosek za svih 12 populacija je bio13,69 $\pm 0,58$ kućica po čauri. Slično tome, Onć-Jovanović i sar. (2011) su utvrdili da je prosečan broj kućica po čauri iste vrste bio 14

Prečnik čaura populacija različitog geografskog porekla kretao se od 15,46 $\pm 2,90 \mathrm{~mm}$ (GRE)

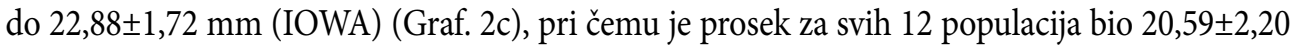
$\mathrm{mm}$. Populacije CRO, GRE, HUN, SER i SLO su imale manji prečnik od prosečnog, dok su ostale populacije dale čaure većeg prečnika. Ipak, čaure svih navedenih populacija su bile znatno manjeg prečnika u odnosu na prosečan prečnik čaura od $30 \mathrm{~mm}$, koji su utvrdili Onć-Jovanović i sar. (2011).

Od svih ispitivanih generativnih parametara, produkcija semena po biljci ima najveći značaj, jer od ovog parametra zavise rezerve semena u zemljištu i širenje populacije korovske vrste. Produkcija semena može da se iskaže preko broja ili mase semena po biljci ili jedinici površine. Tako su Cardina i saradnici (1995) utvrdili da se produkcija semena A. theophrasti kada raste u kompeticiji sa kukuruzom kreće između 100 i 18000 semena $\mathrm{m}^{-2}$ u zavisnosti od vremena nicanja. S druge strane, Lindquist i saradnici (1996) su utvrdili da produkcija semena ove vrste u uslovima kompeticije sa sojom iznosi između 40,37 i 48,93 semena po biljci. Produkcija semena u našem istraživanju je iskazana kao masa semena po biljci i jako je varirala između populacija. Najmanja masa semena $(0,83 \pm 1,44 \mathrm{~g} / \mathrm{biljci})$ je izmerena za populaciju GRE, a najveća $(14,12 \pm 12,08 \mathrm{~g} / \mathrm{biljci})$ za populaciju IOWA (Graf. 2d). Većina populacija (CRO, GRE, HUN, ITA, POR, SER, TOS) je imala produkciju manju od proseka za svih 12 populacija, koji je iznosio 7,11 $\pm 3,62 \mathrm{~g} /$ biljci (Tab. 4). Ipak, ostvarena produkcija semena većine populacija je bila znatno veća od produkcije semena biljaka ove vrste koja je prethodno utvrđena u našim agroekološkim uslovima. Naime, kada je $A$. theophrasti gajen u monokulturi njegova produkcija je bila2,0-4,4 g semena po biljci, a kada je gajen u kompeticiji sa kukuruzom 1,8-3,7 g semena po biljci (OnćJovanović, 2014). 

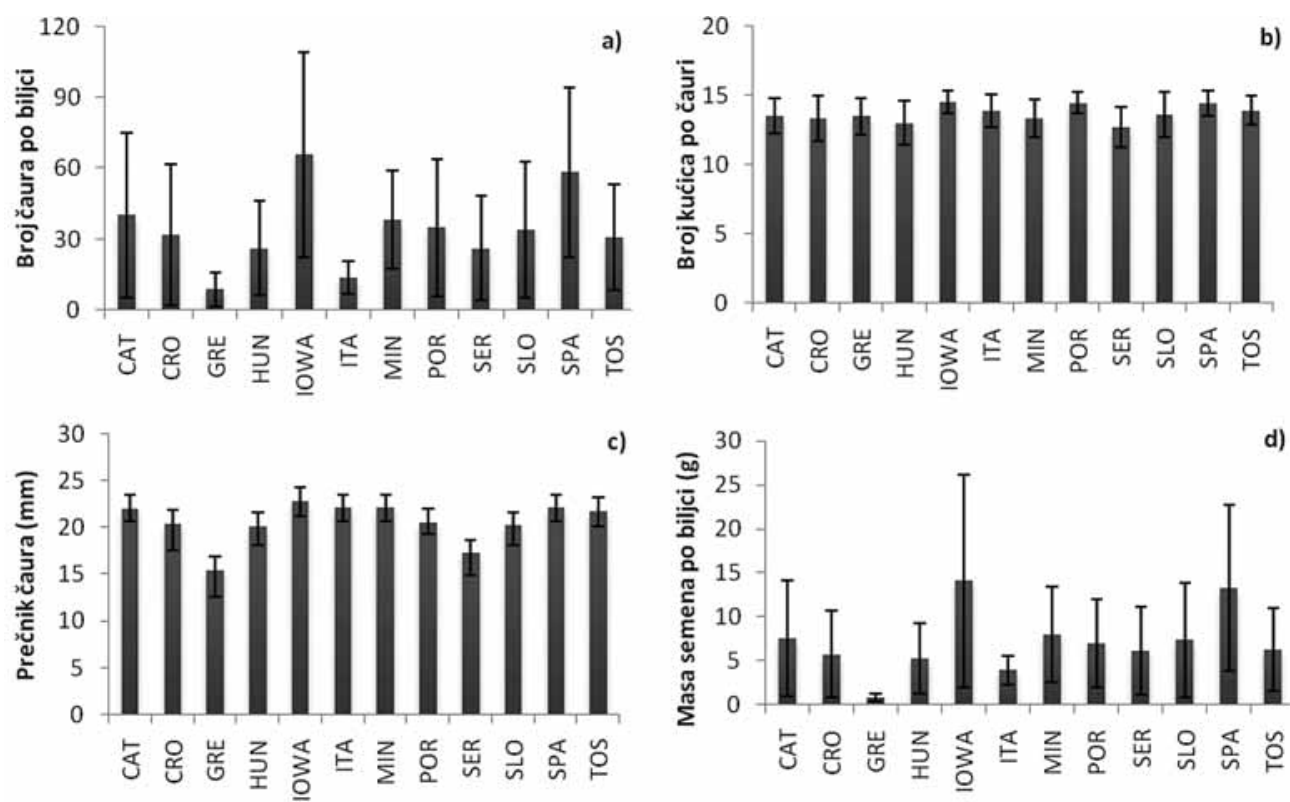

Grafikon 2. Prosečne vrednosti \pm SD generativnih parametara A. theophrasti različitog geografskog porekla: a) broj čaura po biljci, b) broj kućica po čauri, c) prečnik čaure, d) masa semena po biljci

Figure 2. Average values $\pm S D$ of generative parameters of $A$. theophrasti from different geographical origins: a) the number of capsules per plant, b) the number of locules per capsule, c) diameter of capsule, d) weight of seeds per plant

Tabela 4. Karakteristike populacija A. theophrasti u odnosu na prosečne vrednosti generativnih parametara za svih 12 populacija

Table 4. Characteristics of $A$. theophrasti populations in comparison with average values of generative parameters for all 12 populations

\begin{tabular}{|c|c|c|c|c|c|c|c|c|c|c|c|c|c|}
\hline & Prosek $\pm S D$ & 它 & 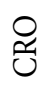 & 岑 & Z & $\underbrace{1}_{0}$ & 岕 & 光 & ̊̊. & 舀 & $\stackrel{0}{\sqrt{n}}$ & 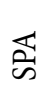 & $\mathscr{0}$ \\
\hline \multirow{2}{*}{$\begin{array}{l}\text { Broj čaura } \\
\text { po biljci }\end{array}$} & $<34,10 \pm 16,08$ & & + & + & + & & + & & & + & & + & + \\
\hline & $>34,10 \pm 16,08$ & + & & & & + & & + & + & & + & & \\
\hline \multirow{2}{*}{$\begin{array}{l}\text { Broj kućica } \\
\text { po čauri }\end{array}$} & $<13,69 \pm 0,5863$ & + & + & + & + & & & + & & + & + & & \\
\hline & $>13,69 \pm 0,5863$ & & & & & + & + & & + & & & + & + \\
\hline \multirow{2}{*}{$\begin{array}{l}\text { Prečnik čaure } \\
(\mathrm{mm})\end{array}$} & $<20,59 \pm 2,20$ & & + & + & + & & & & & + & + & & \\
\hline & $>20,59 \pm 2,20$ & + & & & & + & + & + & + & & & + & + \\
\hline \multirow{2}{*}{$\begin{array}{l}\text { Masa semena } \\
\text { (g)/biljci }\end{array}$} & $<7,11 \pm 3,62$ & & + & + & + & & + & & + & + & & & + \\
\hline & $>7,11 \pm 3,62$ & + & & & & + & & + & & & + & + & \\
\hline
\end{tabular}


Analizom merenih parametara (visina biljaka, dužina korena, broj bočnih grana, broj listova po biljci, broj čaura po biljci, broj kućica po čauri, prečnik čaure i masa semena po biljci) ispitivane populacije $A$. theophrasti poreklom iz 12 geografskih područja su razvrstane na osnovu biološke produkcije u sledeći opadajući niz: $\mathrm{SPA}>\mathrm{IOWA}>\mathrm{POR}>\mathrm{CAT}>\mathrm{SLO}>\mathrm{MIN}>\mathrm{TOS}$ $>\mathrm{CRO}>\mathrm{ITA}>\mathrm{GRE}>\mathrm{HUN}>\mathrm{SER}$. U ovom nizu populacija SPA je postigla najveću, a populacija SER najmanju biološku produkciju.

\section{ZAKLJUČAK}

Biološka produkcija populacija $A$. theophrasti različitog geografskog porekla gajenih $\mathrm{u}$ istovetnim agroekološkim uslovima se razlikovala između populacija. Kod vegetativnih parametara najizraženije razlike između populacija su zabeležene kod površine listova. Površina listova populacije SPA značajno se razlikovala od istog parametra populacija GRE, SER, HUN i ITA. Takođe, populacija IOWA je imala znatno veću površinu listova u odnosu na populacije SER i GRE. Kod generativnih parametra najizraženije razlike su utvrđene za broj za broj čaura i masu semena po biljci. S obzirom da su sve populacije gajene u istim agroekološkim uslovima pretpostavlja se da su utvrđene razlike posledica genetičkih razlika između ispitivanih populacija, što bi trebalo potvrditi analizama na molekularnom nivou.

\section{ZAHVALNICA}

Publikovanje ovih rezultata podržali su projekti III 46008 i EU FP7-REGPOT-AREA.

\section{LITERATURA}

Bello, I.A., Owen, M.D.K, Hatterman-Valenti, H.M.: Effect of shade on velvetleaf growth, seed production, and dormancy. Weed Technology, 9, 452-455, 1995.

Benvenuti, S., Macchia, M., Stefani, A.: Effect of shade on reproduction and some morphological characteristics of Abutilon theophrasti Medicus, Datura stramonium L. and Sorghum halepense L. Pers. Weed Research, 34, 283-288, 1994.

Cardina, J., Regnier, E., Sparrow, D.: Velvetleaf competition and economic thresholds in conventional- and no-tillage corn. Weed Science, 43, 81-87, 1995.

Evetts, L. L. , Burnside, O. C.: Early root and shoot development of nine plant species. Weed Science, 21, 289-291, 1973. 
Hartzler, R.G.: Velvetleaf (Abutilon theophrasti) population dynamics following a single year's seed rain. Weed Technolology, 10, 581-586, 1996.

Lindquist, J.L., Mortensen, D.A., Clay, S.A., Schmenk, R., Kells, J.J., Howatt, K., Westra, P.: Stability of corn (Zea mays) - velvetleaf (Abutilon theophrasti) interference relationships. Weed Science, 44, 309-313, 1996.

Lindquist, J.L., Mortensen, D.A., Johnson, B.E.: Mechanism of corn tolerance and velvetleaf suppressive ability. Agronomy Journal, 90, 787-792, 1998.

Onć-Jovanović, E., Božić, D., Vrbničanin, S.: Productivity of velvetleaf (Abutilon theophrasti Medik.) depend on its density in corn. Banat's Journal of Biotechnology, II, 42-49, 2011.

Onć-Jovanović, E.: Kompetitivna interakcija useva kukuruza i korovske vrste Abutilon theophrasti Medik. Magistarska teza, Univerzitet u Beogradu, Poljoprivredni fakultet, Beograd-Zemun, 2014.

Robbins, W.W., Weier, T.E., Stocking, C. R.: Botany: Plant Science, 3rd edition, Wiley International, New York, 1965.

Sattin, M., Zanin, G., Berti, A.: Case history for weed competition/population ecology: velvetleaf (Abutilon theophrasti) in corn (Zea mays). Weed Technology, 6, 213-219, 1992.

Stoller, E.W., Wax, LO.M., Alm, D.M.: Survey results on environmental issues and weed science research priorities within the corn belt. Weed Technology, 7, 763-770, 1993.

Teasdale, J.R.: Influence of corn (Zea mays) population and row spacing on corn and velvetleaf (Abutilon theophrasti) yield. Weed Science, 46, 447-453, 1998.

Tremmel, D.C., Bazzaz, E.A.: How neighbor canopy architecture affects target plant performance. Ecology, 74, 21142124, 1994.

Vrbničanin, S., Šinžar, B.: Elementi herbologije sa praktikumom. Poljoprivredni fakultet i Zavet, Beograd, 2003.

Vrbničanin, S., Malidža, G., Stefanović, L., Elezović, I., Stanković-Kalezić, R.: Distribucija nekih ekonomski štetnih, invazivnih i karantinskih korovskih vrsta na području Srbije. I deo: Prostorna distribucija i zastupljenost osam korovskih vrsta na području Srbije. Biljni lekar, XXXVI, 303-313, 2008.

Warwick, S.I. , Black, L.D.: The biology of Canadian Weeds, 90. Abutilon theophrasti. Canadian Journal of Plant Science, 68, 1069-1085, 1988.

Warwick, S.I. , Black, L.D.: Geneological variation in recently established populations of Abutilon theophrasti (velvetleaf). Canadian Journal of Botany, 64, 1632-1643, 1986.

\section{SUMMARY}

Biological production of 12 populations of weed species Abutilon theophrasti Medik. from different geographical origin was studied in our agroecological conditions. Seeds of these populations were collected at the stage of physical maturity at the following locations: Catalonia-Spain (CAT), Croatia (CRO), Greece (GRE), Hungary (HUN), Iowa-USA(IOWA ), Legnaro-Italy (ITA), Minnesota-USA (MIN), Portugal (POR), Serbia (SER), Slovenia (SLO), Arganda-Spain (SPA) i Piza- Italy (TOS). In the autumn of 2013 seeds were planted at the Experimental farm of Faculty of Agriculture „Radmilovac“ with density 1 plant per $0.25 \mathrm{~m}^{2}$. At the stage of maturity numerous vegetative (plant height, root length, the number of branches, the number of leaves, leaf area) and generative (the number of capsules per plant, the number of locules per capsule, diameter of capsule, weight of seeds per plant) parameters were measured. 
Comprehensive analysis of the measured parameters was confirmed that the biological production of the studied populations differ, whereby these differences depended on the observede parameters. For vegetative parameters, differences were most pronounced for leaf area. For generative parameters differences between populations were most pronaunced for the number of capsules per plant and weight of seeds per plant.

Keywords: Abutilon theophrasti Medik., biological production, geographical origin, vegetative production, generative production. 